\title{
in Drosophila melanogaster
}

\section{ABSTRACT}

Spire works with Cappuccino to build actin filaments in the cell. Both proteins play an important role in polarity establishment in Drosophila oocytes and embryos by constructing an actin meshwork in the oocyte. Spire that Myosin $V$ Spire and Cappuccino construct. Previous research sugests that Myosin $V$ Myosin $V$ is activated by Spire, but that the binding of Myosin $V$ and Spire has no effect on Spire's activity. The purpose of this study is to measure binding of Myosin V and Spire and understand how it affects each of thei functions. In order to do so, we purified fragments of the two proteins from E. coli. In order to test for binding of Spire and Myosin V, we performed a pulldown assay. We saw binding with wildtype Spire and Myosin V. When either Spire or Myosin V are mutated at the predicted interface, binding is greatly reduced compared to binding of wildtype Spire and wildtype Myosin $V$. This shows that mutating either Spire or Myosin V affects binding of the two proteins. In the future, will perform functional assays with the proteins ncluding analyzing Spire's actin assembly activities. We will also clone mutations to make transgenic animals (Drosophila). We predict that the disruption of binding between Spire and Myosin V will have an effect on cell polarity in Drosophila oocytes and embryos.

\section{INTRODUCTION}

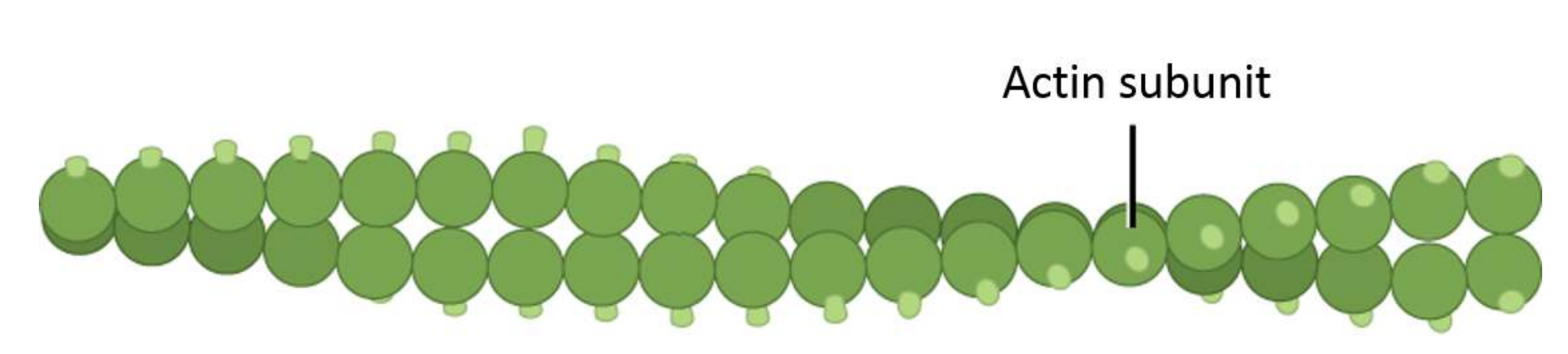

Figure 1. Actin filaments

The cell cytoskeleton is comprised of three different types of cytoskeletal filaments. One of these, actin filaments, is made up of linear polymers of globular actin (G-actin) subunits.

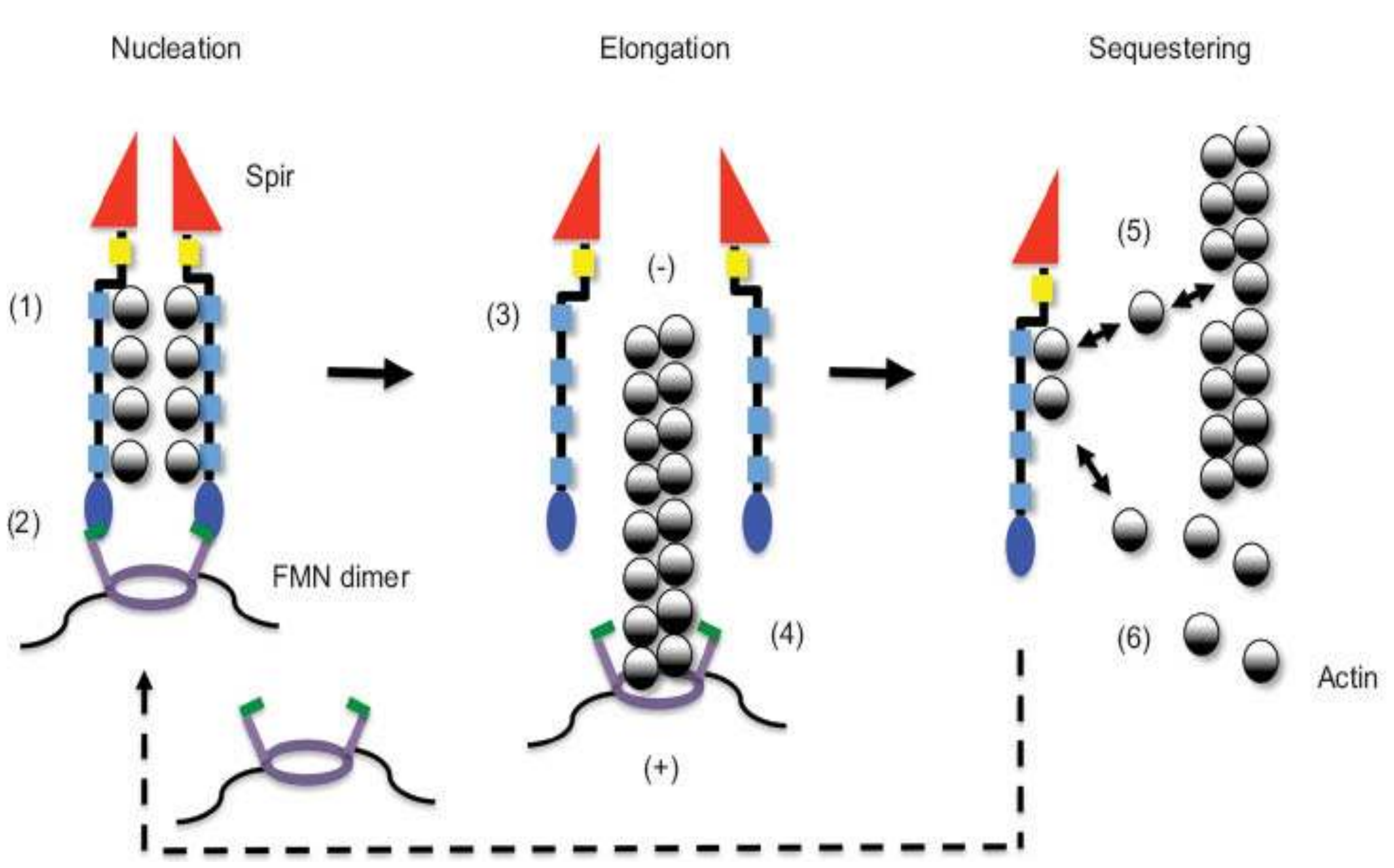

Figure 2. Model of Spire/Formin interaction in actin nucleation Spire (Spir) proteins and Formin (FMN) proteins cooperate in the organization of actin
meshwork.

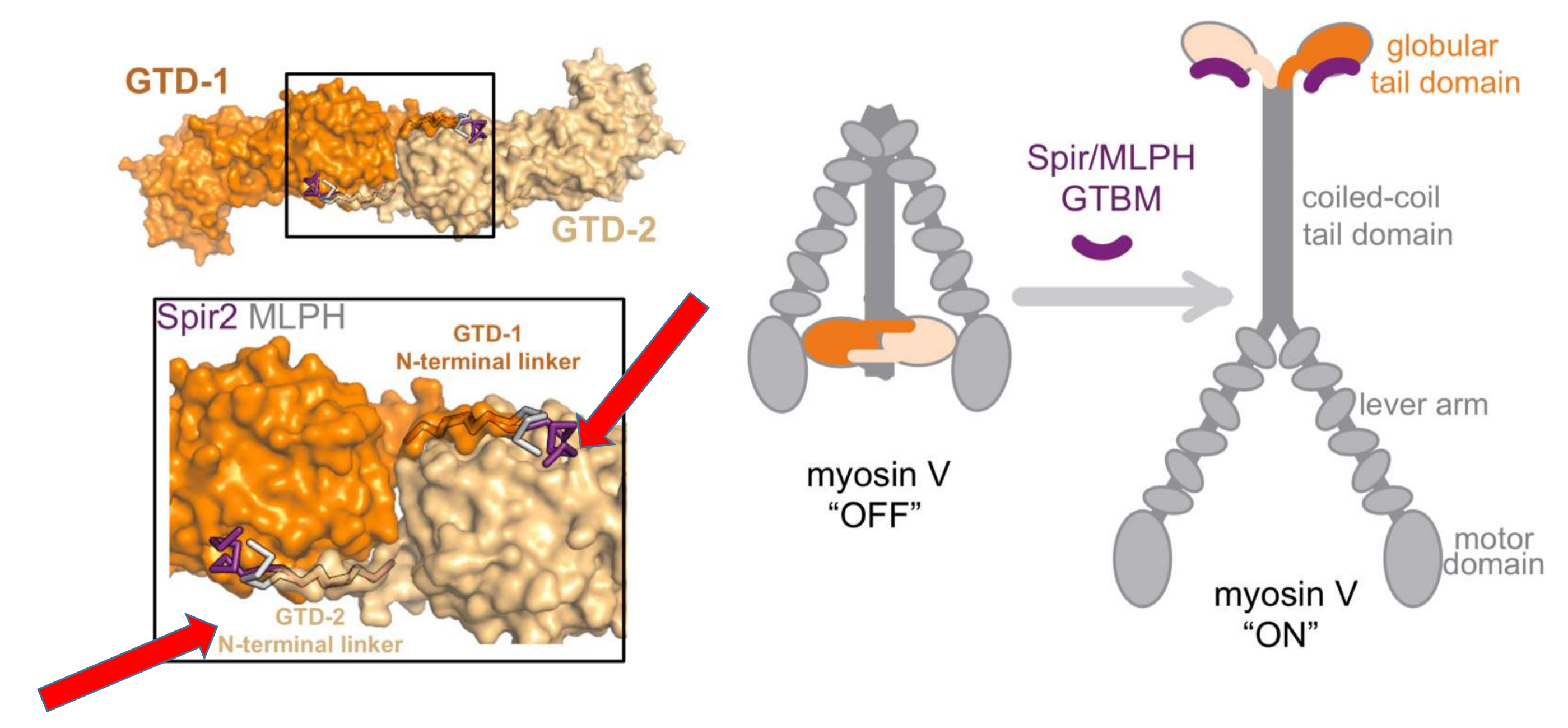

Figure 3. Spire and Myosin V interact

Myosin V (MyoV) is a motor protein that assists vesicle transport. Previous research

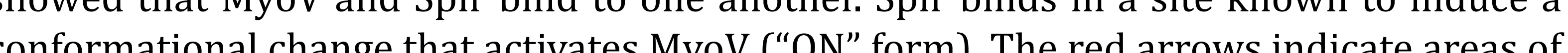
amino acid residue mutations on Spir/MyoV.

\section{HYPOTHESIS}

- Myosin V is activated by Spire, but the binding of Myosin V and Spire has no effect on Spire's activity.

- Mutating either Myosin V or Spire disrupts binding between the two proteins.

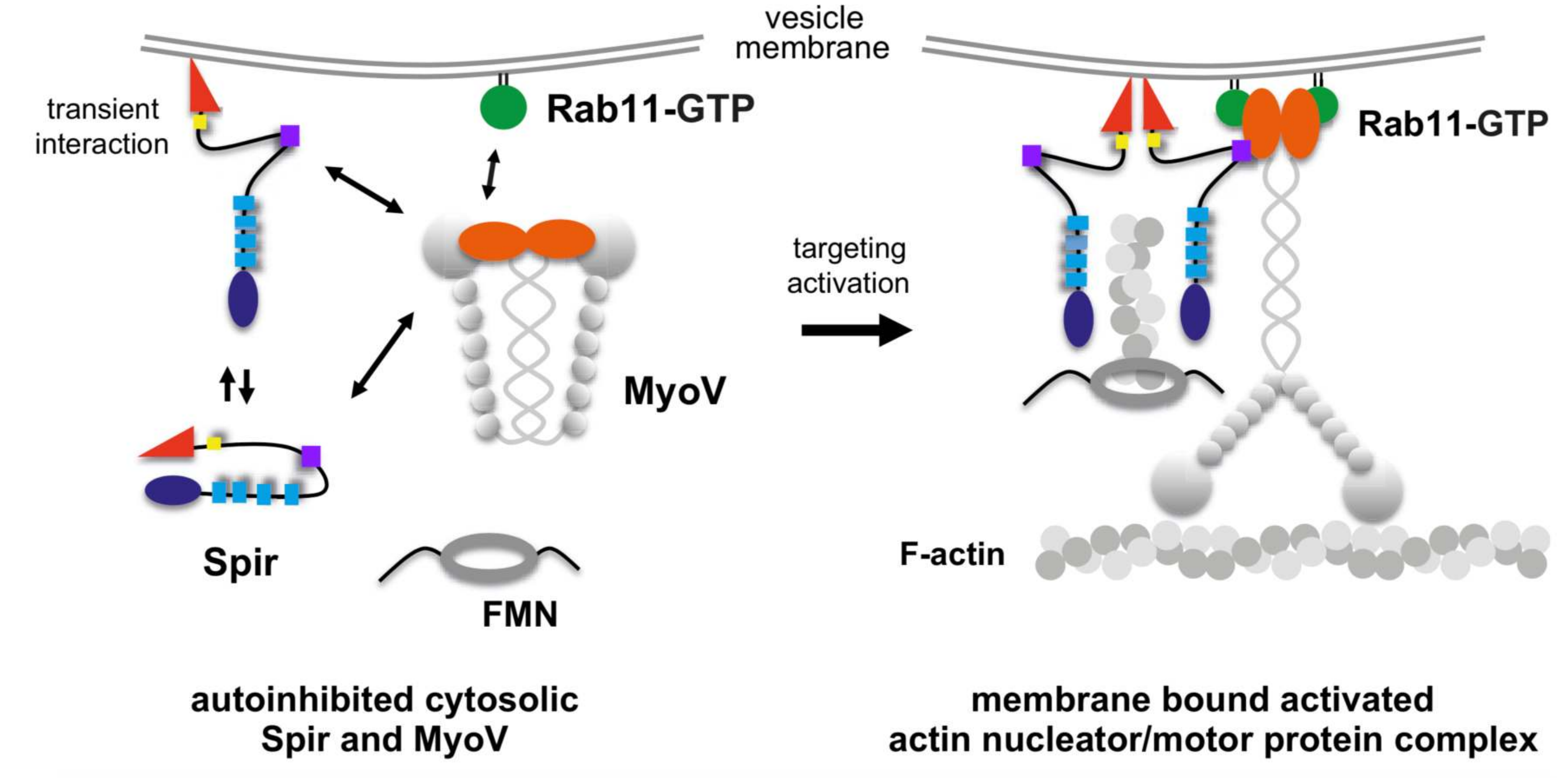

Figure 4. Model of coordinated assembly of Spir/FMN and MyoV Spir and FMN interact to construct the actin filament that MyoV travel on. Spir binds on protein). Our project is designed to test this model.

\section{METHODS AND MATERIALS}
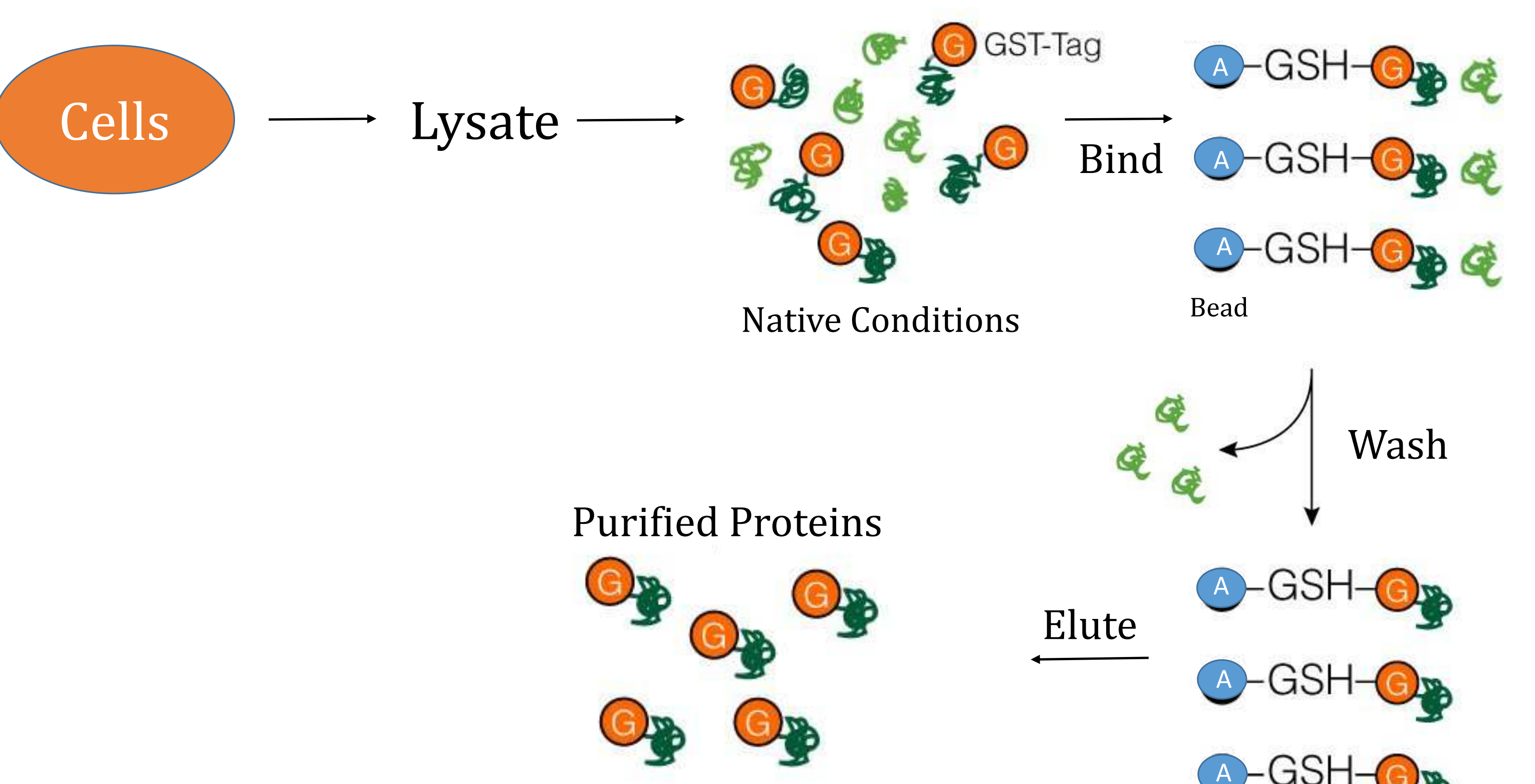

$$
\begin{aligned}
& \text { A-GSH-G } \\
& \text { A-GSH-G } \\
& \text { A-GSH-G }
\end{aligned}
$$

Figure 5. Protein Purification

We purified our protein of interest from E. Coli. We grew bacteria and added IPTG to induce expression of protein. Next, we harvested the cells and lysed them with microinization to obtain the proteins. Then we separated the soluble proteins from insoluble proteins by centrifugation. Afterwards, we put our sample over resin and incubate. Lastly, we perform washes and elution with a gravity column.

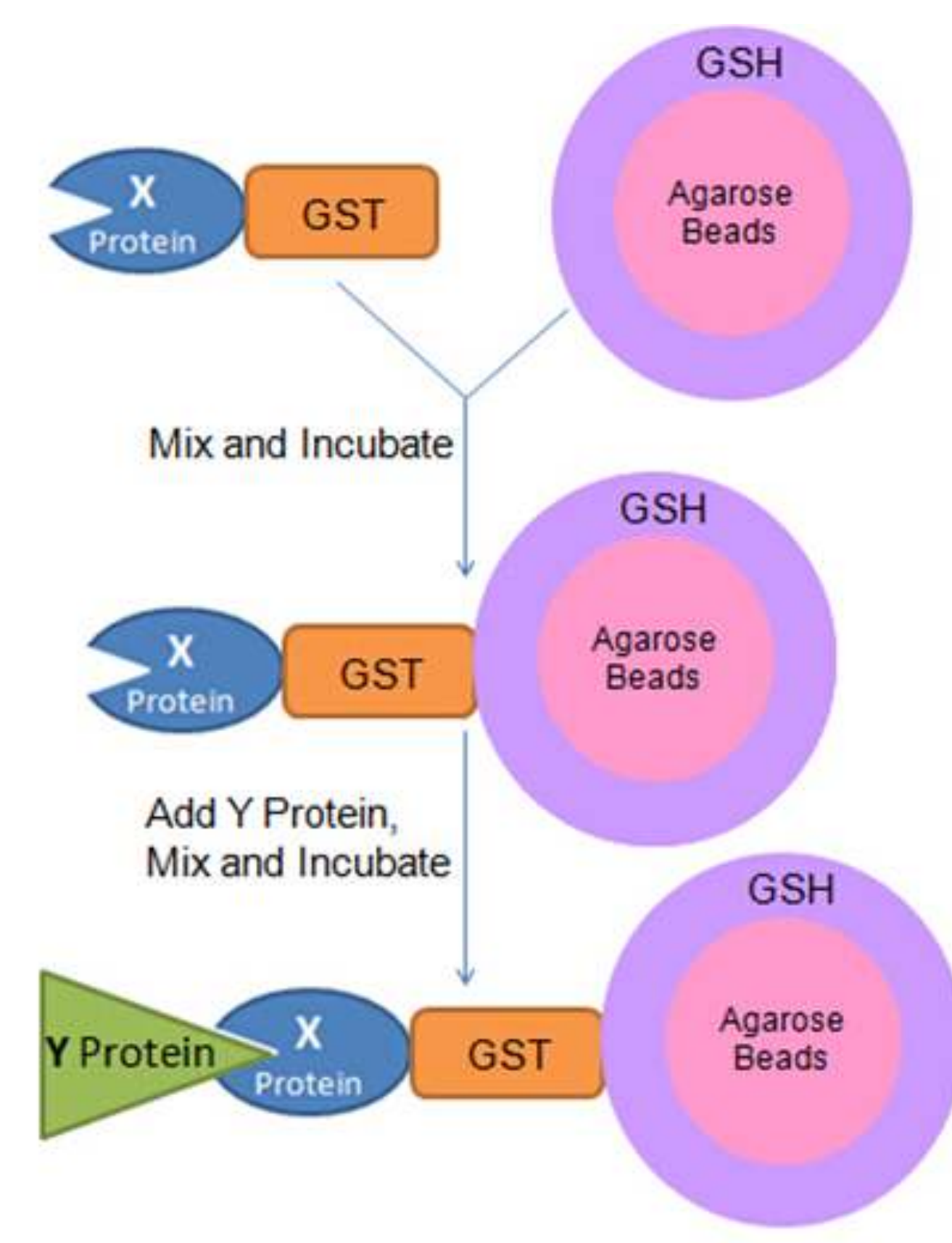

Pulldown Assay GST tag was incorporated with a target protein (X Protein) that we believed binds to its respected protein partner. This tagged protein Frm a complex Afterwards another protein (Y Protein) is introduced to the sample and the pulldown assay measures the levels of binding of the newly introduced protein (Y Protein).

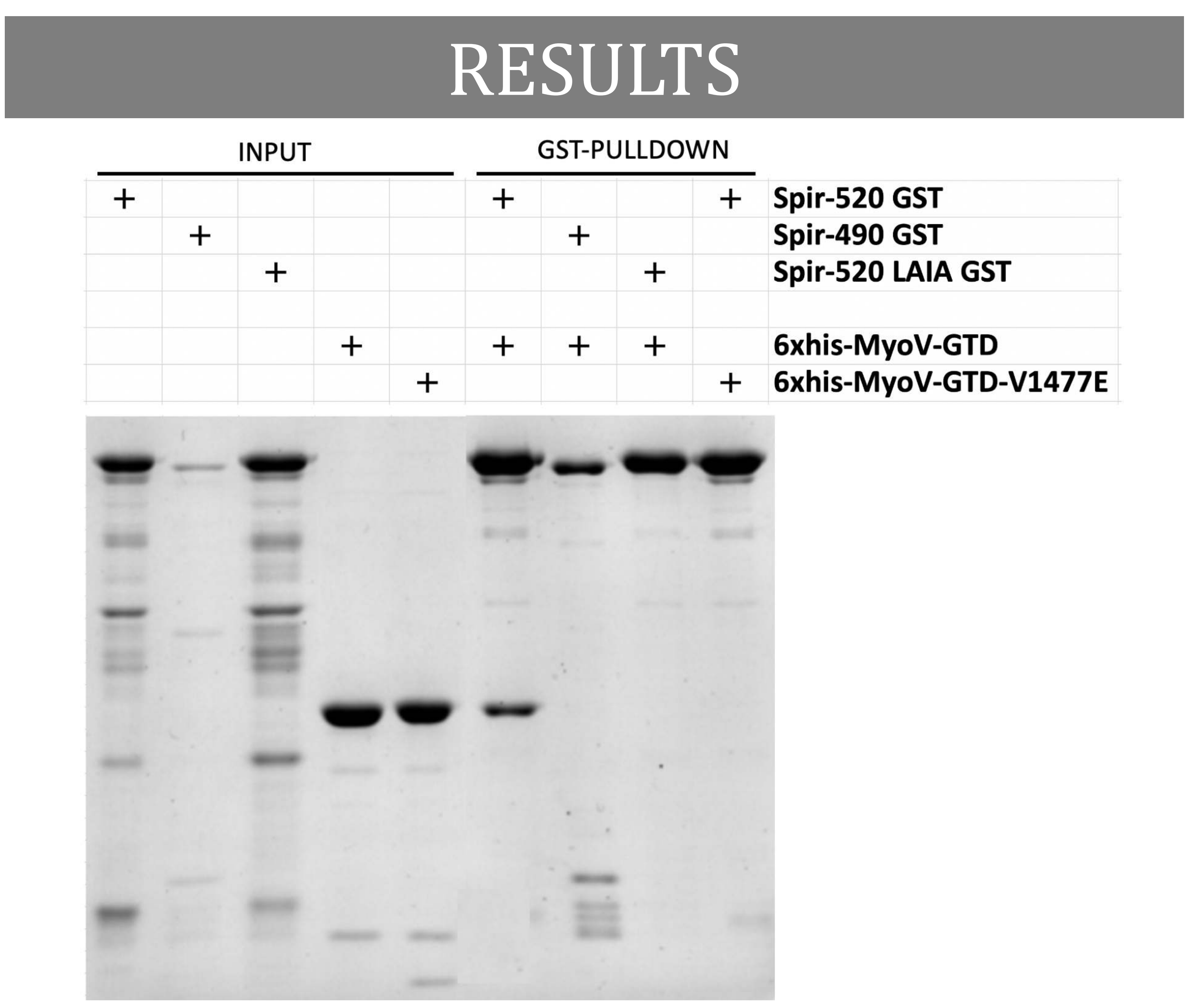

Figure 7. Bacterially expressed Drosophila MyoV and Spir interact SDS-PAGE gel of protein inputs and GST-Pulldowns of mutant Spire and Myosin V.

\section{CONCLUSION}

- Spire and Myosin V interact and bind to one another.

- Mutating either Spire and Myosin V at the predicted binding sites results in disrupted binding to their partner protein.

\section{FUTURE DIRECTIONS}

- Perform functional assays with the proteins

- Assessing Spire's actin assembly activities.

- Clone mutations to make transgenic Drosophila melanogaster.

\section{REFERENCES}

Cooper GM. The Cell. A Molecular Approach. 2nd edition. Sunderland (MA). Shauer Assoctates;

Dahlgaard K, Raposo A, Niccoli T, and Johnston D. Capu and Spire Assemble a Cytoplasmic Actin A the Organization in the Dunctional Insights into the Spir/Formin Actin Nucleator Complex S, Kerkhoff E.

Hammer JA and Sellers JR. Walking to Work: Roles for Class V Myosins as Cargo Transporters

Manseau LF and Schupbach T. Cappuccino and Spire: Two Unique Maternal-effect Loci Required (1437-1452)

Pylypenko O, Welz T, Tittel J, Kollmar M, Chardon F, Malherbe G, Weiss S, Ida Luise Michel C Samol-Wolf A, Till Grasskamp A, Hume A, Goud B, Baron B, England $P$, Titus MA, Schwille $\mathrm{P}$, Myosin V Motors to Rab11 Vesicle Membranes (2016). Two Actin Nucleators, Spire and Cappuccino (2007); 179:1. (117-128). Rohn JL and Baum B. Actin and Cellular Architecture at a glance (2010). (155-158).

\section{ACKNOWLEDGEMENTS}

Research reported in this publication was supported by a grant from the National Institutes of Research repo

The research was supported by the University of California Leadership Excellence through Advanced Degrees (UC LEADS) program. * The consent is solely the responsibility of the authors and does not necessarily represent the 